\title{
International Book Procurement; or, Farmington Extended
}

\author{
By ROBERT VOSPER
}

Philosophically the Farmington Plan (FP) reaches back several decades in the history of American research libraries, for concern with specialization in collection building, with cooperation in procurement, with the inadequacy of our stockpile of basic European research materials, and with coordinated effort in general, is not new to us. Actually, the FP was born from our disconcerting experiences during and immediately following the second World War. A sharply increasing interest in foreign books and journals, at least those of European origin, for the needs both of government and of university research, met with frustration when we were suddenly cut off from the European book markets. The Library of Congress Post-War Mission to Europe, a dramatic episode in American library history that has not been adequately described, helped pick up the slack of European books that had been missed during the war years; at the same time it was a kind of proving ground for the Farmington Plan, which was then under discussion.

As a matter of fact one of the striking, perhaps disconcerting, hallmarks of the FP is the amount of discussion bearing upon it. Five years of discussion went into its making, from the time of the October 1942 meeting at Farmington, Connecticut, of the Executive Committee of the Librarian's Council of the Library of Congress, until the special twoday session of the Association of Research Libraries in March 1947 at which "it was decided to launch the plan with coverage of 1948 publications." Once underway, the plan was the subject of recurrent, often vigorous, discussion at
Mr. Vosper is Director of Libraries, University of Kansas. This paper was presented at the meeting of the Acquisitions Section, ALA Resources and Technical Services Division, Washington, D.C., June 23, 1959.

each semiannual ARL session. Along the way a considerable amount of this discussion, together with other comment, got into print. The history and bibliography of this experience is neatly presented in The Farmington Plan Handbook (Cambridge, 1953) prepared by Edwin E. Williams, together with his series of Farmington Plan Letters, No. 13 of which appeared early this June.

A decade went by, and then at the January 1957 meeting of ARL it was formally voted that "the Farmington Plan Committee, in the light of its ten years of experience, re-examine the purposes, scope and results of the Farmington Plan and report to ARL." Thus another flood of discussion was let loose and your feet are being wetted by it even today. I sometimes think, in my more guilt-stricken moments, that the amount of literature about itself that the FP has produced may be greater than the amount of foreign literature that the plan has brought into this country. This is a sobering thought, but not sufficiently so to restrain me from preparing this paper, which I should entitle "Farmington ad nauseam."

In reality the FP has not produced a large amount of material. In its first ten years of activity it brought in only about 150,000 volumes at a purchase cost of $\$ 275,000$, this being shared among sixty libraries. My own library spends this 
much, or more, in one year for new books and journals. Obviously one of the severe critics of the plan had some basis for his observation that it is "a large, costly, and rather clumsy sledge-hammer to crack so small a nut."

For the FP has indeed had its sharp and persistent critics, and many of the most vocal have been unhappy about either principle or practice. This is the reason for the recent survey, but the surveyors, although their report and recommendations were accepted almost verbatim, are under no illusion that dissatisfaction is now at an end. They are inclined to believe that sheer weight, of bulk if not of argument, was in their lavor. For the finished product presented about three hundred mimeographed pages weighing almost four pounds.

The survey, with the support of a grant from the Council on Library Resources, Inc., was begun in the late fall of 1957; the final report was presented at a January 1959 meeting in Chicago of representatives from all participating libraries, in conjunction with the midwinter session of ARL. During the intervening months the problem was attacked in the following manner: An exploratory questionnaire elicited some specific information and revealed some clear points of tension; personal visits to a large number of participating libraries provided an opportunity for more thorough discussion, not just of Farmington operations but also, and more importantly, of foreign procurement programs in general; several analyses of European book production and of Farmington receipts 1948-1958 provided specific information on the success of the FP effort; and finally a series of special working papers commented on the procurement needs of American libraries in parts of the world little touched by the existing Farmington activity-Eastern Europe, Latin America, the Far East, and Africa. The questionnaire and the visitations were described by my associate Robert
L. Talmadge in an interim report in the September 1958 issue of $C R L$.

In an attempt to secure better information, in addition to opinion, about the effectiveness of the FP operation and its existing procedures, a series of analytical studies was instituted. The first was based on a random sample group of 205 items pulled from the total records of Farmington receipts during the ten years of operation. Complete bibliographical information was supplied by the forty-six recipient libraries involved, and the 205 items were then checked thoroughly against the National Union Cata$\log$ (NUC). Most importantly, this revealed that 79 of the 205 items, or $381 / 2$ per cent, were apparently held uniquely by the FP recipient libraries. An additional 30 items ( $141 / 2$ per cent of the sample) were held only by the FP recipient and the Library of Congress. This suggested immediately that FP was producing large amounts of uncommon material.

The next step was an attempt to find out whether these 79 unique items were important enough to justify the procurement effort. The recipient libraries were asked to provide qualitative judgments which indicated, in summation, that of 205 items delivered under FP, 26 (121/2 per cent) were unique and desirable items that might otherwise have been missed by interested American libraries. On the other hand, 18 items (almost 9 per cent) of no apparent value to anyone were delivered. On balance, we concluded that FP is producing a good return on the investment, and especially so if by refinement of method we can reduce the 9 per cent of totally unimportant books. The full study of course went into much more detail than can be reported here.

Beyond this general random sample study we tried to analyze receipts from several points of view. We looked at a science (physics), at a social science (French economics and, less specifically, 
Scandinavian history), and at two literatures (Spanish and Scandinavian). We looked at Scandinavia where the book trade and the bibliography are first rate, and we looked at Spain where these factors are less satisfactory. We looked at a country and a subject widely studied in American universities (French economics); and we looked at Danish literature which is less frequently studied and taught in this country. We looked at countries where the FP agent is a book dealer, as well as at France where the national library acts as agent. We looked at France which has a large book production, as well as at countries relatively smaller in output of books.

In one study two major French journals in economics were culled for reviews of, or citations to, economics books published in France 1950-1954, and these 378 items were compared with the actual FP receipts and checked on a sampling basis against NUC. In another study Bibliotheca Hispana of 1954 was reviewed by a specialist for all books that appeared, from the listing, to be worth acquiring and keeping for research purposes. These 191 desirable books were then compared with actual FP deliveries and checked against NUC.

From these and from the several other analyses of a decade of FP procurement in Western Europe we concluded that the FP experience has indeed been valuable. It has apparently strengthened our stockpile of desirable books more than many of us had realized. We concluded also that this demonstrated the value of "blanket orders" under certain circumstances, a conclusion contrary to the opinion of most librarians with whom we had talked earlier. At the same time it was clear that our total foreign procurement effort has been short of success, and that an intensified and refined effort is required in the future if the expressed needs of American research libraries are to be met. In order to achieve a greater measure of success through the
FP operation, we recommended a greater degree of discrimination-from country to country, from subject to subject, and from time to time-in the selection pattern. We felt that the procurement effort must be monitored more steadily by the interested libraries, and that they must act with greater intelligence and selectivity in order to secure more of the important books that we now miss and in order to forego some of the dross that we have been receiving. We saw the need for a less monolithic FP operation, the need for an operation that demands the application of more individual intelligence and effort.

But the overweening conclusion we came to was that there is continued, in fact, heightened, need for a nationally planned procurement program for foreign books, and, further, that such a coordinated procurement program cannot overlook any part of the world, not even Western Europe.

There had been some strong opinion that perhaps FP had served its purpose, and served it well, in Western Europe, but that the time had come when it could be abandoned in that part of the world. This opinion was based on the assumption that in the intervening ten years American libraries have become more vigorous and effective in their acquisitions program, while at the same time the Western European book market has become much more efficient. Our studies seem to suggest, however, that on the one hand we are still not procuring all of the important books we think we want, and that on the other hand a great many American libraries still feel that they are being served well by the kind of operation represented thus far by FP.

This is perhaps the point at which to discuss very briefly a semantic problem that has been with us for a good long time. There has been a ready tendency to identify FP only with a particular procurement procedure whereby as- 
signed dealers select books for all recipient libraries. It is important, however, to keep in mind the fact that FP is not merely a particular acquisitions procedure. It is in fact a broad concept that is world-wide in scope. This concept was stated in the earliest days of FP development: "Its objective is to make sure that at least one copy of each new foreign book and pamphlet that might reasonably be expected to interest a research worker in the United States will be acquired by an American library, promptly listed in the Union Catalog at the Library of Congress, and made available by inter-library loan or photographic reproduction." Much of the unhappiness over FP has been unhappiness, often not thoroughly justified, with the particular operational pattern employed for Europe rather than with this basic concept. It was the conclusion of the surveyors that the operational pattern established in Western Europe is basically sound but that it requires definite modification in the interests of greater discrimination and efficiency.

Much of the difficulty over FP selection developed during the earliest days when there was some confusion as to whether FP was serving the needs of university research or the needs of governmental intelligence. The latter factor had probably loomed large in the early days during and just after the war. In the intervening years, however, it is quite clear that the federal government has become much more sophisticated in its intelligence effort and that other organizations, with enormous funds and skill, are taking care of the basic intelligence needs insofar as the procurement of printed material is concerned. Thus it becomes quite clear that FP as it now proceeds must be concerned specifically with the needs of university-centered research, as seen by the participating libraries. Another point of confusion that was discussed, if not fully resolved, related to the belief that FP is an experi- ment in subject specialization among libraries on a national scale. The facts do not appear to bear this out. We are perhaps wiser to think of FP only as an effort to systematize foreign procurement looking toward adequate coverage on a national basis.

The very fact that so many librarians had begun to feel that normal procurement efforts were probably acquiring all of the necessary books from Western Europe led us to inquire about foreign procurement programs of American libraries. Our findings were not particularly optimistic. In most cases-even in some of the largest, wealthiest, and most distinguished institutions-book selection, as we saw it, is a harrying and intermittent task, based dominantly on faculty recommendations that are in fact little coordinated and seldom monitored. In a few cases, to be counted on the fingers of one hand, there are book selection staffs within the library. But these staffs are not large numerically, and often there is but one brilliant polymath involved. Occasionally reference people or other members of the library staff make recommendations for purchases as a part-time aspect of some other regular and demanding assignment. The detailed checking of national bibliographies by subject fields is quite uncommon; among faculty book selectors the national bibliography is almost unknown. In general, book selection at the university level appears to be far from precise. It is further confused, as far as the FP concept is concerned, by the fact that faculty members as book selectors are very seldom consistent or even thoughtful about the importance of thorough coverage of currently published foreign books.

This general impression strengthened our feeling that there continues to be need even in Western Europe for an organized national procurement effort. At the same time, we certainly hope that the need will eventually pass. 
Once we step outside Western Europe, however, the whole question of the need for a nationally planned procurement effort becomes far less debatable. This would have been clear without any special study. It is interesting to note that at the time FP was being restudied a number of groups quite outside the library field, or only peripheral to it, were making vigorous efforts to expand the library procurement effort to the more difficult parts of the world. The American Council of Learned Societies, the Social Science Research Council, and the Association for Asian Studies have established committees or joint committees within the past few years in order to foster library acquisitions from the Far East, from South Asia, from the Middle East, and from Eastern Europe. For three years the homeless but well organized and well-informed Latin American Acquisitions Seminars have been pressing for a nationally planned procurement effort for Latin America. At the same time the federal government, through Public Law 480, has begun to set up machinery and funds for the procurement of library materials from certain difficult parts of the world. You will recall that for a number of understandable reasons the FP effort had made little impression outside Western Europe.

Therefore, it seemed to the surveyors, it is incumbent upon organized American research libraries to coordinate and rationalize this whole expanding need for foreign books and journals. We proposed that recognition be given to the fact that FP was supposed to become world-wide in scope; we urged that immediate steps be taken to move in this direction. The result is that the FP committee structure has now been strengthened and extended by area subcommittees which are charged specifically with working with other interested scholarly groups. In March, just after a session at Princeton at which this organization was formally established, members of the newly expanded committee went on to Washington for meetings with existing committees concerned with Far Eastern and South Asian library resources. One ARL participant who had been somewhat skeptical of an expanded FP program indicated subsequently that these Washington meetings "gave ample evidence of the intent of many people to increase and systematize the acquisitions of American university libraries from areas hitherto dealt with only accidentally."

As a portion of the survey, a group of extremely informative area working papers helped bring into focus this significant change in the foreign procurement needs of American libraries. In 1948 our horizon was bounded by $\mathrm{Eu}$ rope; in 1958 it was clearly world-wide, and this shift had developed so rapidly and on so many fronts that American research libraries were on the verge of losing the initiative through sheer inertia. These several area working papers should be read carefully by a wider audience than the initial publication could reach. They analyzed publishing output and costs as well as the extent to which this is relevant to the needs of American research; and they discussed procurement procedures and problems. It was quite clear that these several factors varied widely from area to area. The percentage of the extensive Japanese annual book production that is useful to American research and the number of libraries deeply interested therein is one thing; the depth of our interest in Latin Ameriican books and the number of libraries interested is another. The organization of the Russian book trade and the consequent procurement problem is markedly different from the Indian or Middle Eastern situation, to say nothing of that in Central Africa. Nor can the language problem be overlooked in this expanding international effort.

It was amply clear from these several 
studies not only that we need a Farmington effort throughout the world but that it must be a flexible effort, adjusting to these various factors of publishing output, procurement possibilities, and the extent and depth of current American interests. The assigned dealer technique has apparent validity still for Western Europe, but different techniques must be applied elsewhere. These same factors called for an organizational structure that will permit librarians to work closely with specialists, both within libraries and throughout the scholarly community.

These were the primary implications of the ten-year survey. It was also noted that United States libraries are not alone in attempting to coordinate the national foreign procurement effort. In differing ways, the British libraries, the research libraries of West Germany, and those of the Scandinavian countries individually as well as collectively, have been developing their own programs concurrently. Recent information on the German and Scandinavian experiences was reported in the FP survey.

Two questions were not fully resolved. The surveyors were unable fully to come to grips with the question of serial literature. We proposed to tighten up existing procedure for reviewing new periodical titles and recommended further study of this whole vexing question developed during the course of the survey itself. It seemed apparent from some of the sampling studies of European procurement that there is probably inadequate duplication in this country of the more important current foreign books. We were concerned about this not for reasons of security; we were concerned because several of the largest research libraries in the country appear to be increasingly, although perhaps unduly, restive under the heavy interlibrary loan business they must service, while at the same time we are witnessing the rise of a large number of newly chartered uni- versity centers all across the country. This expansion of American higher education will surely only increase the pressure on existing strong collections. It is the urgent opinion, at least of the writer of this paper, that steps should be taken to encourage more university libraries to do a fair job of foreign procurement, at least insofar as the most important books and journals are concerned. Incidentally, this writer also believes firmly that collectively we must dedicate ourselves afresh and with new heart to the interlibrary loan business, even on an international basis, because the ready sharing of books, or copies thereof, is basic to any national effort to systematize foreign procurement. Some of the recent grumbling about the cost and burden of interlibrary lending is in bad taste, to say the least.

On the question, however, of this possible need for a greater duplication of certain foreign books, one peculiar misunderstanding needs to be cleared up. Many libraries, both FP participants and others outside the scheme, have felt they could not share in the FP procurement effort unless specifically assigned to a subject. This is not true. In fact, libraries are welcome and even urged unilaterally to share in the benefits of the organized procurement pattern. Just because geology happens now to be assigned to UCLA does not mean that other libraries must refrain from using the FP dealer to secure equal coverage in geology. Other libraries are welcome to do so; they need not even seek permission. Any library, whether or not presently involved in FP, may write to any or all FP-assigned dealers and arrange to receive a complete duplicate FP shipment in any number of subjects. Billing and shipping are direct, with the one exception of France where a change is soon due, so there is no reason for confusion. The official subject assignments then clo not preclude comparable unofficial assignments. A case in point,

COLLEGE AND RESEARCH LIBRARIES 
and a successful one, involves Spanish literature, where Illinois is the official FP library; Wisconsin some years ago asked the FP agent in Spain to send Wisconsin duplicate shipments and found this very much to their advantage. More of this type of arrangement is in order. Although permission is not required, the pertinent subcommittee would like to know of such developments, which might well be listed centrally for general information.

This then was the FP survey. Its basic findings were summarized in a series of recommendations that were adopted with only minor changes by the participating libraries at the January 1959 meeting and recommended to ARL as the operating agency; ARL thereupon agreed to them and proceeded, in a special administrative session at Princeton in March, to set up committee machinery. The basic resolutions and the new committee structure are appended herewith for general information.

\section{ReCOMMENDATIONS AdOPTEd ON 26 JANUARY 1959}

1. "Leadership in the development and coordination of major scholarly acquisitions programs of national scope and importance should be accepted as a major and continuing ARL responsibility.

2. "The coordinated effort to assure adequate coverage of currently published foreign library materials of scholarly importance should be extended and strengthened, on a world-wide basis.

3. "The Farmington Plan Committee should be chartered and supported as the responsible, central committee for ARL in this whole field. Toward this end, the Committee should be adequately staffed, and should be authorized to proceed as may be necessary through subcommittees and co-opted members. It should be responsible for continuous liaison with all appropriate library, scholarly, educational, and governmental bodies, as well as with appro- priate joint committees. The Committee's activities should encompass continuous study and assessment of needs, operation of programs, and review and analysis of programs in action.

4. "ARL should continue to seek, or itself provide, funds for secretarial and research assistance for the Committee and its office. If possible the Committee chairman and the office should continue to be located together.

5. "Certain operating patterns of the Farmington Plan, as they have developed particularly in Western Europe, should be modified along lines mentioned by the survey report: looking toward a more flexible and decentralized selection and procurement pattern, while still assuring that adequate records are maintained for purposes of study and review. In accomplishing this, a subcommittee on procurement from Western Europe may be in order.

6. "The strengthened Farmington Plan Committee should give high priority to fostering and experiment with flexible, coordinated procurement efforts in other parts of the world, along lines recommended in the area working papers; in pursuing this task the Committee will need to develop effective relationships, as noted in (3) above, with the appropriate working committees in the several areas, in order to be certain of receiving adequate specialized advice.

7. "Prior to the development of a systematic procurement program for better coverage of foreign periodicals, the Farmington Plan Committee should institute some sample studies, along lines proposed in working paper III, to ascertain the adequacy of our holdings, especially in the humanities and social sciences, as well as in engineering. In the meantime, steps should be taken to tighten up procedure for securing, selecting, and recording sample issues of new periodicals.

8. "Attention should be given to the need for more extensive duplication 
among American libraries of the important, currently published foreign books. Multiple use of assigned Farmington Plan agents, in important fields, offers one ready-made procedure toward this end.

9. "ARL should continue to bring forcefully to the attention of appropriate governmental agencies, educational bodies, and foundations that the national pool of research books and journals is of high national importance, that an effectively coordinated national program for world-wide coverage is an expensive but urgent undertaking, and that adequate assistance through direct, long-term financing and through staff aid is in the national interest."

Committee Structure AS OF June 1959

1. The reconstituted and reorganized Farmington Plan Committee is to have general responsibility for the development and implementation of the Farmington Plan, but will delegate responsibility for specific areas of the world to a series of subcommittees. It consists of a chairman (Robert B. Downs), two members-at-large (Lewis Branscomb and Rutherford Rogers), ARL chairmen of the area committees (as listed below), and the ARL Executive Secretary $e x$ officio (William S. Dix).

2. Membership of the area subcommittees:

Committee on Slavic Resources: Douglas Bryant, Harvard University, Chairman.

Committee on Near Eastern Materials: Frederick Wagman, University of Michigan, Chairman; Richard Logsdon, John Cronin, Douglas Bryant (or Philip McNiff, alternate).

Committee on Far Eastern Resources: Philip McNiff, Harvard University, Chairman.

Committee on African Resources: Jens Nyholm, Northwestern University, Chairman; James W. Henderson, David Jolly, Robert D. Baum (representing the African Studies Association).

Committee on Latin American Reources: Stanley West, University of Florida, Chairman.

Committee on South Asian Resources: Donald Coney, University of California, Chairman; Herman Fussler, Frederick Wagman.

Committee on Western European Resources: Robert Vosper, University of Kansas, Chairman; Harald Ostvold, Helen M. Welch.

\section{Midwest Librarians Conference}

The fifth annual Midwest Academic Librarians Conference will be held at Grinnell College, Grinnell, Iowa, on Friday and Saturday, April 29-30. As in past Conferences, the program will consist principally of discussions of various topics relating to academic librarianship by small groups of conferees. There will in addition be two programmed speeches. Grinnell's President Howard Bowen will speak on "Sending Dollars to College" at the Friday evening dinner meeting, and a speaker is to be selected for the luncheon meeting on Saturday. Russell Dozer, MALC chairman, and his staff at Grinnell College Library will be hosts at the Conference. 